\title{
Ecological significance of seed germination characteristics in flood-meadow species
}

\author{
Norbert Hölzel*\& Annet te Ot te \\ Department of Landscape Ecology and Resources Management, Justus Liebig University Giessen, Heinrich-Buff-Ring 26-32, \\ D-35392 Giessen, Germany
}

Submitted: May 27, $2003 \cdot$ Accepted: Oct 2, 2003

\begin{abstract}
Summary
In climate chamber and outdoor experiments we analysed germination traits of 42 vascular plant species typical of floodmeadows of the alliance Cnidion. In Central Europe such flood-meadows and their highly endangered character species are confined to large lowland river corridors with a dry and warm climate. Due to the prevailing ecological conditions, particularly the extremely high variability in soil moisture potential, it was hypothesised that flood-meadow species exhibit specific strategies in terms of germination phenology, temperature requirements and primary dormancy to avoid constraints on seedling recruitment imposed by flooding, drought and competition from established vegetation. Furthermore, we expected that germination characteristics could be a key for the causal understanding of range size, confinement to large river corridors, recent rarification processes, seed bank persistence and establishment success in restoration projects.

PCA ordination of germination traits reflected a continuous gradient of increasing primary dormancy levels ranging from species with a high capacity for fast and almost complete germination over a wide range of temperatures to those with high and narrow temperature requirements and/or a delayed and asynchronous emergence. Many of the studied species germinated only at relatively high temperature in the year of shedding, but the primary conditional dormancy disappeared in most cases after a period of cold wet stratification. Requirements for chilling and/or high germination temperature were revealed to be the most common strategies for avoidance of harmful autumn and winter germination. The majority of the studied species tends to exploit particularly favourable regeneration niches in early spring. Surprisingly, many species with large long-term persistent soil seed banks exhibited relatively low dormancy levels in light; this was correlated with small seed size and a consequent higher probability of burial. We found no relationship between germination characteristics and river corridor confinement or Central European range size. However, there was a significant trend in endangered species towards higher temperature requirements and delayed, asynchronous germination. This is presumably disadvantageous under the environmental conditions of subcontinental flood-meadows.
\end{abstract}

Key words: Dormancy, germination temperature requirements, grassland restoration, principal component analysis, seed bank, stratification

\section{Introduction}

The temporal and spatial limitation of the "regeneration niche" (Gr u bb 1977) has been increasingly identified as one of the most critical constraints in the life-cycle of plant populations, and is a factor that may severely reduce diversity in plant communities (e. g. St a mpfl i \&
Zeit e r 1999). Recruitment from seeds is often strongly hampered or even condemned to failure through competition by established vegetation (Rusch \& FernándezPal acios 1995; Kot or ová \& Lepš 1999; Touzard et al. 2002) as well as unfavourable environmental conditions such as frost and drought (Silvertown \& Dickie 1980; Ryser 1993). Consequently, successful

* Corresponding author: Department of Landscape Ecology and Resources Management, Justus Liebig University Giessen, Heinrich-Buff-Ring 26-32, D-35392 Giessen, Germany; e-mail: norbert.hoelzel@agrar.uni-giessen.de 
germination and seedling establishment in a given species will often depend on its ability to avoid or minimize such constraints. Numerous previous studies have shown that seeds of many species boast the aptitude to identify suitable conditions for seedling recruitment (Grime 2001). Narrow temperature requirements, dormancy cycles induced or broken by temperature fluctuations, warm or cold stratification, as well as other environmental factors, such as fire or nitrate concentrations, are all mechanisms that regulate the onset of germination and help in detection of favourable micro-sites with low competition (Th o mpson et al. 1977; Grime et al. 1981; Baskin \& Baskin 2001; Hroudová \& Zákravsky 2003). Such dormancy breaking mechanisms were revealed to be of particular importance in species typical of temperate wet grasslands (e.g. Mil berg 1994; Sch ütz 1997; Knödler 2001; Jensen 2001).

Germination characteristics may play an equally important role in the formation of persistent soil seed banks. Seeds exhibiting conditional or strict dormancy (Baskin \& Baskin 2001) are more likely to be buried and to establish large persistent reservoirs in the soil (Thompson et al. 1993; Grime 2001). Seed regeneration strategies are now considered as a key for the causal understanding of the decline, persistence or spread of species in changing landscapes (e. g. Sch üt z 2000b).

Information on germination characteristics is also particularly relevant for habitat restoration, in which species-enrichment largely depends on re-establishment by artificially introduced or naturally dispersed seeds (e. g. Bakker \& Berendse 1999; Patzelt et al. 2001). By the creation of suitable regeneration niches at the right time of the year, management schemes may positively influence germination and the subsequent fate of seedlings (Ol ff et al. 1994; Kot or ová \& Lepš 1999; $\mathrm{Schütz} 2000 \mathrm{~b}$ ). If seeds of target species are introduced artificially, information on germination phenology, dormancy, response to storage and pre-treatments are essential to increase the likelihood of seeding success (Keller \& Koll mann 1999; Budel sky \& Galat ow it sch 1999). However, knowledge on germination characteristics is still extremely scarce particularly in rare and endangered species targeted for conservation and there are a great variety of possible response types (e.g. Baskin \& Baskin 2001). This also applies to declining and endangered species-rich flood-meadows of the alliance Cnidion that include a large number of rare plant species of Central European conservation concern (Schnittler \& Günther 1999; Hölzel et al. 2002). In their Central European distribution these alluvial grasslands are strictly confined to large river corridors with dry and warm subcontinental climatic conditions (Kor sch 1999; Burkart 2001). This distribution pattern is reflected by the occurrence of many highly spe- cialised eastern species that are uncommon in Central Europe and close to the western limit of their range, such as Allium angulosum, Cnidium dubium, Scutellaria hastifolia and Viola pumila (Hultén \& Fries 1988). Ecologically these flood-meadows are characterized by an extremely high variability in soil water potential (Burkart 1998; Leyer 2002). Whereas winter, spring and early summer may often bring floods summers are markedly dry and rapidly hardening clay soils are common (Dist er 1980; Hölzel 1999). Thus, successful seedling recruitment may be hampered by flooding as well as by drought (Höl zel \& Ot te 2003a) and there is only a relatively narrow time window with favourable germination conditions.

In the present study, we investigated if there is a specific response in germination characteristics of the typical flora of flood-meadows to these particular ecological conditions. Furthermore, we attempted to assess whether germination characteristics can provide an explanation for the strict confinement of many character species to large river corridors with subcontinental climatic conditions. According to their Central European distribution pattern, it is postulated that characteristic flood-meadow species tend to have high temperature requirements for germination.

The study was carried out in the framework of a large-scale restoration project aimed at the re-establishment of species-rich flood-meadows on ex-arable land by the transfer of diaspores with plant material from remnant stands (Höl zel \& Harn isch 2002; Höl zel \& Ot t e 2003). It is often claimed (e.g. Patzelt 1998; Sch üt z 2000b) that declining, rare and endangered species tend to have detrimental germination requirements. Thus, we expected that germination traits could be a key to detect the underlying mechanisms of successful or failing re-establishment of target species as well as for the optimisation of restoration measures.

\section{Material and Methods}

\subsection{Study species}

Seeds of 42 species were collected in bulk from autochthonous populations in flood-meadows along the northern Upper Rhine River, Germany, between the tributaries Neckar to the south and Main to the north. Seed sampling took place between May and October depending on the time of ripening and included at least 50 different plant individuals. The species studied comprise typical constituents of subcontinental flood-meadows, representing a broad variety of families, life forms and strategy types (Table 1). Besides character species, which are more or less confined to large lowland river corridors such as Allium angulosum, Arabis nemorensis, Cnidium dubium, Iris spuria, Scutellaria hastifolia and Viola pumila (Burkart 2001) we 
Table 1. Traits of the studied species according to the following authors: Life form (El lenberg et al. 1992), seed mass (Höl zel \& Ot te 2003/4a), river corridor area (Kor sch 1999 and Burkart 2001), German Red List status (Korneck et al. 1996). Letters in bold indicate abbreviations for species names used in following tables and figures. Life forms: $\mathrm{T}=\mathrm{Therophyte}$, $\mathrm{G}=$ Geophyte, $\mathrm{H}=$ Hemicryptophyte. Confinement to river corridors : ++ strong, + weak, - none. Red List status : $1=$ critically endangered, 2 = endangered, 3 = vulnerable, - = not threatened.

\begin{tabular}{|c|c|c|c|c|c|}
\hline Species & Family & $\begin{array}{l}\text { Life } \\
\text { form }\end{array}$ & $\begin{array}{l}\text { Seed mass } \\
(\mathrm{mg})\end{array}$ & $\begin{array}{l}\text { River } \\
\text { corridor }\end{array}$ & $\begin{array}{l}\text { Red } \\
\text { List }\end{array}$ \\
\hline Allium angulosum & Liliaceae & $\mathrm{G}$ & 1.74 & ++ & 3 \\
\hline Alopecurus pratensis & Poaceae & $\mathrm{H}$ & 0.71 & - & - \\
\hline Althaea officinalis & Malvaceae & $\mathrm{H}$ & 3.41 & + & 3 \\
\hline Arabis nemorensis & Brassicaceae & $\mathrm{H}$ & 0.06 & ++ & 2 \\
\hline Barbarea stricta & Brassicaceae & $\mathrm{H}$ & 0.41 & ++ & - \\
\hline Cardamine parviflora & Brassicaceae & $\mathrm{T}$ & 0.07 & ++ & 3 \\
\hline Carex praecox & Cyperaceae & $\mathrm{H}$ & 0.16 & + & 3 \\
\hline Carex spicata & Cyperaceae & $\mathrm{H}$ & 3.34 & - & - \\
\hline Carex tomentosa & Cyperaceae & $\mathrm{H}$ & 1.44 & - & 3 \\
\hline Cerastium dubium & Caryophyllaceae & $\mathrm{T}$ & 0.11 & ++ & 3 \\
\hline Cirsium tuberosum & Asteraceae & $\mathrm{H}$ & 2.27 & - & 3 \\
\hline Cnidium dubium & Apiaceae & $\mathrm{H}$ & 0.39 & ++ & 2 \\
\hline Elymus repens & Poaceae & $\mathrm{H}$ & 4.50 & - & - \\
\hline Euphorbia palustris & Euphorbiaceae & $\mathrm{H}$ & 10.47 & ++ & 3 \\
\hline Festuca arundinacea & Poaceae & $\mathrm{H}$ & 3.16 & - & - \\
\hline Galium boreale & Rubiaceae & $\mathrm{H}$ & 0.68 & - & - \\
\hline Galium wirtgenii & Rubiaceae & $\mathrm{H}$ & 0.40 & + & - \\
\hline Inula britannica & Asteraceae & $\mathrm{H}$ & 0.09 & ++ & - \\
\hline Inula salicina & Asteraceae & $\mathrm{H}$ & 0.16 & - & - \\
\hline Iris spuria & Liliaceae & G & 14.62 & ++ & 2 \\
\hline Lathyrus palustris & Fabaceae & $\mathrm{H}$ & 12.85 & + & 3 \\
\hline Lythrum salicaria & Lythraceae & $\mathrm{H}$ & 0.06 & - & - \\
\hline Peucedanum officinale & Apiaceae & $\mathrm{H}$ & 12.32 & + & 3 \\
\hline Poa angustifolia & Poaceae & $\mathrm{H}$ & 0.21 & - & - \\
\hline Potentilla reptans & Rosaceae & $\mathrm{H}$ & 0.31 & - & - \\
\hline Pseudolysimachion longifolium & Scrophulariaceae & $\mathrm{H}$ & 0.05 & ++ & 3 \\
\hline Pulicaria dysenterica & Asteraceae & $\mathrm{H}$ & 0.04 & - & - \\
\hline Rumex thyrsiflorus & Polygonaceae & $\mathrm{H}$ & 0.54 & + & - \\
\hline Sanguisorba officinalis & Rosaceae & $\mathrm{H}$ & 1.95 & - & - \\
\hline Scutellaria hastifolia & Lamiaceae & $\mathrm{H}$ & 0.68 & ++ & 2 \\
\hline Selinum carvifolia & Apiaceae & $\mathrm{H}$ & 1.06 & - & - \\
\hline Senecio paludosus & Asteraceae & $\mathrm{H}$ & 0.62 & ++ & 3 \\
\hline Serratula tinctoria & Asteraceae & $\mathrm{H}$ & 1.26 & - & 3 \\
\hline Silaum silaus & Apiaceae & $\mathrm{H}$ & 2.43 & - & - \\
\hline Symphytum officinale & Boraginaceae & $\mathrm{H}$ & 3.65 & - & - \\
\hline Thalictrum flavum & Ranunculaceae & $\mathrm{H}$ & 0.80 & ++ & - \\
\hline Valeriana pratensis & Valerianaceae & $\mathrm{H}$ & 0.62 & ++ & - \\
\hline Veronica peregrina & Scrophulariaceae & $\mathrm{T}$ & 0.06 & + & - \\
\hline Veronica serpyllifolia & Scrophulariaceae & $\mathrm{H}$ & 0.05 & - & - \\
\hline Viola elatior & Violaceae & $\mathrm{H}$ & 1.80 & ++ & 2 \\
\hline Viola persicifolia & Violaceae & $\mathrm{H}$ & 0.68 & ++ & 2 \\
\hline Viola pumila & Violaceae & $\mathrm{H}$ & 1.08 & ++ & 2 \\
\hline
\end{tabular}

also studied more common and widespread components like Festuca arundinacea, Potentilla reptans, Rumex thyrsiflorus, Symphytum officinale and Veronica serpyllifolia. The study covers almost the entire spectrum of regionally rare and endangered target species of flood-meadows (Kor neck et al. 1996). Plant nomenclature follows Wisskirchen \& Haeupler (1998).

\section{$14 \quad$ FLORA (2004) 199}

\subsection{Experiment 1}

After field collection seeds of the 40 species used in this experiment were stored dry in darkness at room temperature (ca. $20^{\circ} \mathrm{C}$ ) until further use during the following winter season. The germination experiments were performed by spreading 50 
seeds of each species on a double layer of filter paper in sterile Petri dishes. In case of very large seeds only 25 seeds per dish were used. Five dishes per treatment were incubated in climate chambers at constant temperatures of 3, 7, 10, 15, 20, 25,30 , and $35^{\circ} \mathrm{C}$ and in a further chamber with diurnally fluctuating temperatures $5 / 15^{\circ} \mathrm{C}(8 / 16$ hours). The latter temperature regime was also applied to seeds that received cold wet stratification at $3{ }^{\circ} \mathrm{C}$ for 8 weeks prior the incubation, which should mimic early spring germination conditions. The light regime in the climate chambers simulated long day conditions with 16 hours of light and 8 hours of darkness. The dishes were regularly watered with distilled water to optimise moisture conditions. The experiment lasted 6 weeks. Germinated seeds were counted and removed once every week. Germination was defined as the emergence of the radicule.

\subsection{Experiment 2}

Results obtained in climate chambers are often strongly divergent from those set up in outdoor germination experiments, and certain species may even completely fail to germinate under laboratory treatments (e. g. Gr ime et al. 1981; Pat zel t 1998). Thus, we combined both approaches in order to investigate germination phenology under more natural conditions.

A total of 800 seeds of each species were sown in February into two Styrofoam basins $(18 \mathrm{~cm} \times 28 \mathrm{~cm})$ filled with sterile garden soil and exposed at an experimental field near Giessen, Germany. During dry periods the basins were watered daily. Emerging seedlings were counted and removed at least every two weeks. The outdoor study was continued for 24 months.

\subsection{Experiment 3}

To investigate primary dormancy levels (Baskin \& Baskin 2001) and the timing of germination under near natural conditions, seeds from a subset of 20 species were collected at the time of shedding in the field and exposed about 2 weeks later under outdoor conditions. The mode of exposure and counting was principally the same as in experiment 2 . In contrast to natural field conditions the 800 sown seeds were watered regularly during dry periods.

\subsection{Characterisation of germination}

For each laboratory and outdoor treatment, the percentage of seeds that had germinated after the end of the observation period was determined. To correlate temporal patterns of outdoor germination with thermal conditions we used meteorological data from the nearby (ca. $500 \mathrm{~m}$ ) climate research station Linden. Starting on the last day with a daily average temperature below $1{ }^{\circ} \mathrm{C}$ we calculated the number of days with daily averages above $5^{\circ} \mathrm{C}$ as well as total temperature sums of daily averages until the onset and the first pronounced peak in outdoor germination, respectively. Both temperature traits revealed to be highly correlated $\left(r^{2}=0.98\right)$, thus we used only the number of days with averages above $5{ }^{\circ} \mathrm{C}$ for further numerical analyses.
To describe germination characteristics for each species the following values were calculated:

$L O P T$, the optimal temperature for germination, was calculated as weighted average of germination rates over all constant temperatures in the climate chamber experiment, according to the mode described by $01 \mathrm{ff}$ et al. (1994): $\left[\left(3 P_{3}+7 P_{7}+\right.\right.$ $\left.10 P_{10}+15 P_{15}+20 P_{20}+25 P_{25}+30 P_{30}+35 P_{35}\right) /\left(P_{3}+P_{7}+\right.$ $\left.\left.P_{10}+P_{15}+P_{20}+P_{25}+P_{30}+P_{35}\right)\right]$ in which $P_{3}$ was percentage germination at $3^{\circ} \mathrm{C}, P_{7}$ percentage germination at $7^{\circ} \mathrm{C}$, and so on.

LMAX, the maximum germination rate, was defined as the highest percentage of germination in one of the climate chamber treatments after six weeks.

GFAS was the maximum germination rate at constant temperature after 7 days in the climate chamber.

TFAS was the temperature at which GFAS was reached.

$L O W$ was the lowest constant temperature with at least $5 \%$ germination.

$H I G H$ was the highest constant temperature with at least $5 \%$ germination.

$A M P$ was the range in degrees Kelvin between $H I G H$ and LOW.

$A L T$ was the difference in germination rate at fluctuating temperatures of $5 / 15^{\circ} \mathrm{C}$ in comparison to the constant temperature of $15^{\circ} \mathrm{C}$.

STRAT, the effect of cold wet stratification, was the difference in germination rate in comparison with $A L T$.

FMAX was the maximum germination rate under outdoor conditions.

ONSET was the date of outdoor germination begin in days with daily averages above $5^{\circ} \mathrm{C}$ counted from the last day with a daily average below $1^{\circ} \mathrm{C}$.

$F O P T$ was the date of the first germination peak under outdoor conditions (measured as for ONSET).

$P E A K 1$ was the maximum germination during one single count as a percentage of total final outdoor germination.

$P E A K 4$ was the maximum germination during the four following weeks, measured as for PEAKI.

SPAN was the period in days between the first and last count, in which at least $5 \%$ of total final outdoor germination occurred.

\subsection{Data analysis}

The correlation structure of germination traits was investigated by principal component analysis (PCA) on a data matrix with z-transformed standardised variable values (Legen dre \& Legendre 1998). The traits LOPT, TFAS, HIGH and LOW were not included in the analysis because their calculation requires germination under constant temperatures in the climate chamber, which did not occur in a number of species. As PCA does not accept missing values, the inclusion of these traits would have lowered the number of analysed species. Correlations between single germination traits and PCA-axis scores, on the one hand, and species attributes such as seed mass (Höl zel \& Ot te 2003/4a), seed longevity, threat status, range size and type on the other hand were examined by nonparametric Spearman rank correlation coefficients. As a measure of seed longevity we applied the seed accumulation index (SAI) given in Höl zel \& Ot te (2003/4 a) for 36 of the stu-

FLORA (2004) 199 15 


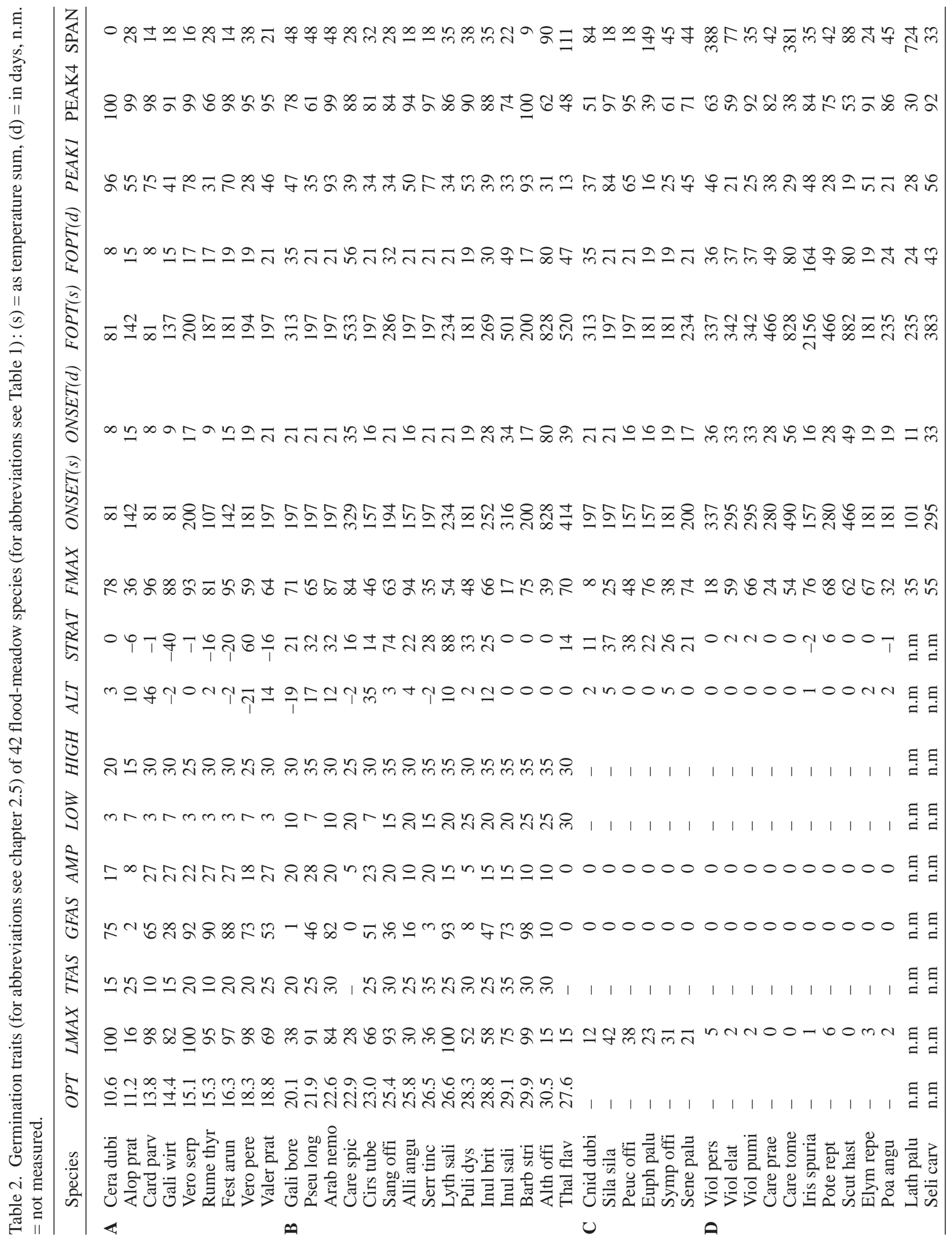

FLORA (2004) 199 
died species. To describe range size on a Central European scale we used grid frequency data from the German flora mapping project provided by the electronic resource Floraweb (BfN 2003). Threat status was assessed by a simple ordinal scale ranging from 0 (unthreatened) to 2 (strongly threatened) based on the list of Korneck et al. (1996). In the same way river corridor confinement was allocated from the specifications of Kor sch (1999) and Burkart (2001). Differences between groups were tested using a non-parametric Mann-Whitney U-test. All calculations were carried out with STATISTICA 6.0 .

\section{Results}

\subsection{Patterns of single germination traits}

Under laboratory conditions only a limited proportion of the studied species (Group A, Table 2) germinated with high rates over a wide range of constant temperatures $(A M P)$ or showed a clear preference for low germination temperatures $(O P T, L O W)$. In contrast, many species reached maximum germination rates only at relatively high constant temperatures $(O P T)$ above $20^{\circ} \mathrm{C}$ (Group B, Table 2). However, in all of these species except Althaea officinalis and Barbarea stricta germination rates increased considerably after 8 weeks of cold wet stratification (STRAT) and following low fluctuating temperatures $\left(5 / 15^{\circ} \mathrm{C}\right)$, most strikingly in Lythrum salicaria and Sanguisorba officinalis. Positive effects of fluctuating temperatures $(A L T)$ alone without stratification were less pronounced and restricted to a few species such as Cardamine parviflora and Cirsium tuberosum. In some other species they even caused a decline in germination rate. In Apiaceae and some other species (Group C, Table 2) germination under laboratory conditions was confined to the stratification treatment (STRAT).

A surprisingly high number of species (Group D, Table 2) almost completely failed to germinate under all laboratory treatments, showing maximum germination rates below $5 \%$. Under outdoor conditions in all of these species (except Cnidium dubium) the germination rates $(F M A X)$ increased considerably and were usually well above $20 \%$.

In the outdoor treatment about half of the species had an initial pronounced germination peak $(F O P T)$ after around 20 days with daily averages above $5^{\circ} \mathrm{C}$, which is equal to a temperature sum of ca. $200^{\circ} \mathrm{C}$. Most species with a highly positive response to the cold wet stratification treatment under laboratory conditions (STRAT) were found within this group. Galium boreale, Cnidium dubium, Sanguisorba officinalis, Selinum carvifolia and all Viola species showed slightly higher temperature requirements $(F O P T)$ with peak germination about two weeks later (around 30 days with averages $>5^{\circ} \mathrm{C}$, temperature sum $>300^{\circ} \mathrm{C}$ ).
However, there were also some species with explicitly deviating behaviour indicating significantly lower or higher temperature requirements. In Cerastium dubium and Cardamine parviflora outdoor germination started considerably earlier $\left(<10\right.$ days with averages $>5^{\circ} \mathrm{C}$, temperature sum $<100^{\circ} \mathrm{C}$ ). In contrast, Althaea officinalis, all Carex species, Inula britannica, I. salicina, Potentilla reptans, Scutellaria hastifolia and Thalictrum flavum showed a much higher temperature requirement with a first germination peak occurring only after 50 days with averages $>5^{\circ} \mathrm{C}$ and a temperature sum $>500^{\circ} \mathrm{C}$. In both response groups these results largely coincided with the germination temperature requirements found in the laboratory experiment.

In $60 \%$ of the studied species more than $80 \%$ of the final outdoor germination took place within four weeks. In some, such as Arabis nemorensis, Cerastium dubium, Serratula tinctoria, Silaum silaus and Veronica serpyllifolia such rates were even reached during a single count. This particularly synchronous germination behaviour is contrasted by other species that emerged over a long period with low but constant rates. This was most obvious in Carex tomentosa, Euphorbia palustris, Scutellaria hastifolia and Thalictrum flavum.

\subsection{Multivariate analysis of germination traits}

The principal-component analysis (PCA) revealed the correlation structure of the germination traits (Table 3 , Fig. 1). The first factor axis, which explained the bulk of the variance $(40.99 \%)$, reflected a continuous gradient from species with high, rapid and strongly synchronised germination over a wide range of temperatures (left side of Fig. 2) to those with high temperature requirements and a delayed germination over a relatively long period (right side of Fig. 2). Factor axis 2 largely coincided with the variation of $A M P, S P A N$ on the one hand and $P E A K 4$ on the other hand. Factor axes 3 and 4 predominantly represented the variance in STRAT and ALT, respectively (Table 3, Fig. 1 and 2).

\subsection{Timing of germination after natural seed shedding}

In experiment 3 , in which the timing of germination after natural seed release was investigated the following major response types appeared (Fig. 3):

I) Potential for complete germination within the season of shedding: Among the species used in this experiment only the therophytes Cardamine parviflora and Cerastium dubium belong to this response type. Seeds of these species reached $100 \%$ of the final germination 
Table 3. Correlation between factor axes of PCA ordination and germination traits. High correlations are given in bold (for abbreviations of germination traits see chapter 2.5).

\begin{tabular}{lrrrr}
\hline & Factor 1 & Factor 2 & Factor 3 & Factor 4 \\
\hline Eigenvalue & 4.51 & 1.34 & 1.19 & 0.96 \\
Variance $(\%)$ & 40.99 & 12.16 & 10.81 & 8.71 \\
LMAX & $\mathbf{- 0 . 8 9}$ & -0.26 & 0.26 & -0.15 \\
GFAS & $\mathbf{- 0 . 8 1}$ & -0.38 & 0.14 & -0.16 \\
AMP & $\mathbf{- 0 . 7 6}$ & $\mathbf{- 0 . 5 0}$ & 0.06 & -0.05 \\
PEAK1 & $\mathbf{- 0 . 6 4}$ & 0,26 & -0.25 & 0.04 \\
PEAK4 & $\mathbf{- 0 . 7 3}$ & $\mathbf{0 . 4 7}$ & -0.22 & -0.06 \\
ALT & -0.35 & -0.24 & 0.05 & $\mathbf{- 0 . 7 8}$ \\
STRAT & -0.08 & 0,29 & $\mathbf{0 . 8 1}$ & -0.25 \\
FMAX & $\mathbf{- 0 . 5 1}$ & -0.28 & -0.42 & -0.29 \\
ONSET & $\mathbf{0 . 6 5}$ & -0.36 & 0.08 & -0.18 \\
FOPT & $\mathbf{0 . 5 9}$ & -0.20 & -0.34 & -0.30 \\
SPAN & $\mathbf{0 . 6 2}$ & $\mathbf{- 0 . 4 3}$ & 0.14 & 0.12 \\
\hline
\end{tabular}

rate within two months after shedding in late May. Whereas germination started directly after sowing in Cardamine parviflora the onset of germination in Cerastium dubium was about 4 weeks later.

II) Potential for partial germination directly after shedding in late summer with a second peak in March/April of the following year: All species belonging to this response group germinated to a certain degree directly after shedding. However, germination stopped abruptly by the end of September at the latest, when daily averages were usually still well above $10^{\circ} \mathrm{C}$. Spring germination, in contrast, started at the earliest in late February, with a significant peak in March at temperatures considerably lower than those in early autumn when germination stopped. Only in Inula salicina did germination start as late as April, indicating significantly higher temperature requirements.

III) No germination in the year of shedding, but almost complete and rapid germination in March/April of the following year: Most species of this group comprise Apiaceae with relatively late seed release (September), but species with a much earlier shedding are also represented, such as Galium boreale. Early spring germination occurred very abruptly and was highly synchronised. Only Cnidium dubium showed a slightly extended germination period towards summer.

IV) Delayed, slow germination over an extended period, starting in the first summer after shedding: In most species of this response type significant germination started no earlier than late April or May and continued over the whole summer season. In Carex tomentosa peak germination occurred only in the second, and in Lathyrus palustris even in the third and fourth year (data not shown) after shedding.

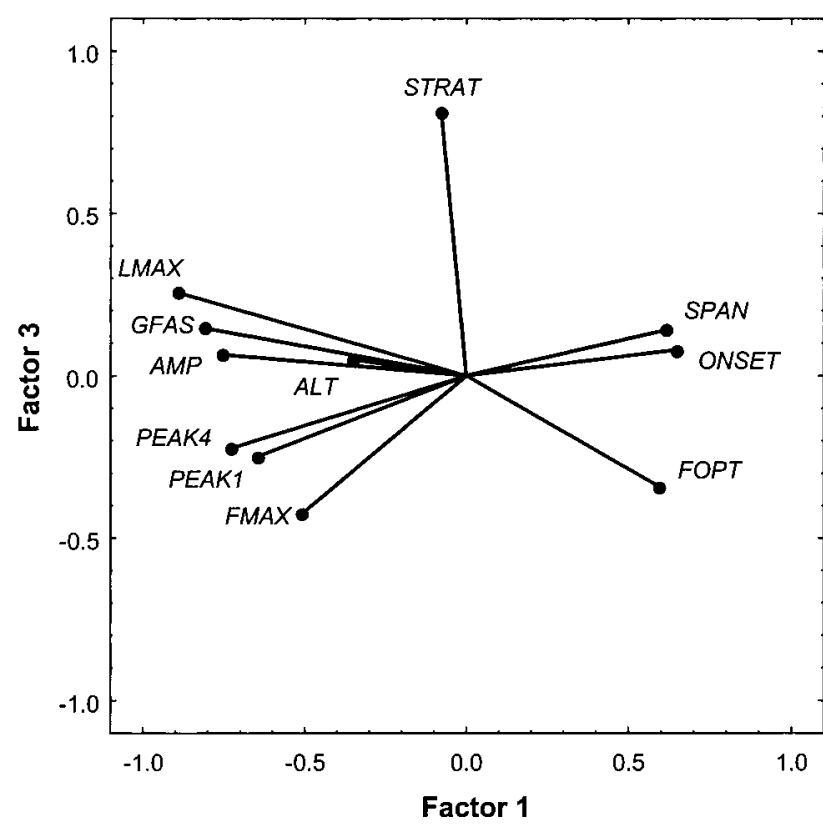

Fig. 1. Biplot displaying correlation structure of germination traits along factor axis 1 and 3 in PCA-ordination (for abbreviations of germination traits see chapter 2.5).

\subsection{Correlation between germination characteristics and other species traits}

According to Spearman rank correlation species with small seed mass tended to germinate faster (GFAS) $(r=-0.51, p<0.001)$ and had a higher temperature amplitude $(A M P)(r=-0.38, p<0.05)$ and maximum germination rate $(L M A X)(r=-0.44, p<0.01)$ under laboratory conditions. No further correlations between seed weight and germination characteristics were found.

Surprisingly, the tendency in species to build up longterm persistent soil seed banks was positively correlated with fast germination under laboratory conditions $(G F A S)(r=0.40 p=0.02)$ and a high outdoor germination rate $(F M A X)(r=0.35 p=0.04)$.

Spearman rank correlation also revealed a significant but relatively weak correlation $(r=0.36 p=0.02)$ between the first factor axis in PCA ordination and Red List status. A similar relationship was found between Red List status and single germination traits such as LMAX $(r=-0.43 p=0.006)$, GFAS $(r=-0.32 p=0.04)$, FOPT $(0.43 p=0.03)$ and SPAN $(r=0.37 p=0.02)$, indicating a trend towards higher dormancy levels, increased temperature requirements and asynchronous germination in endangered species. In contrast, there was no relationship at all between germination traits and river corridor 


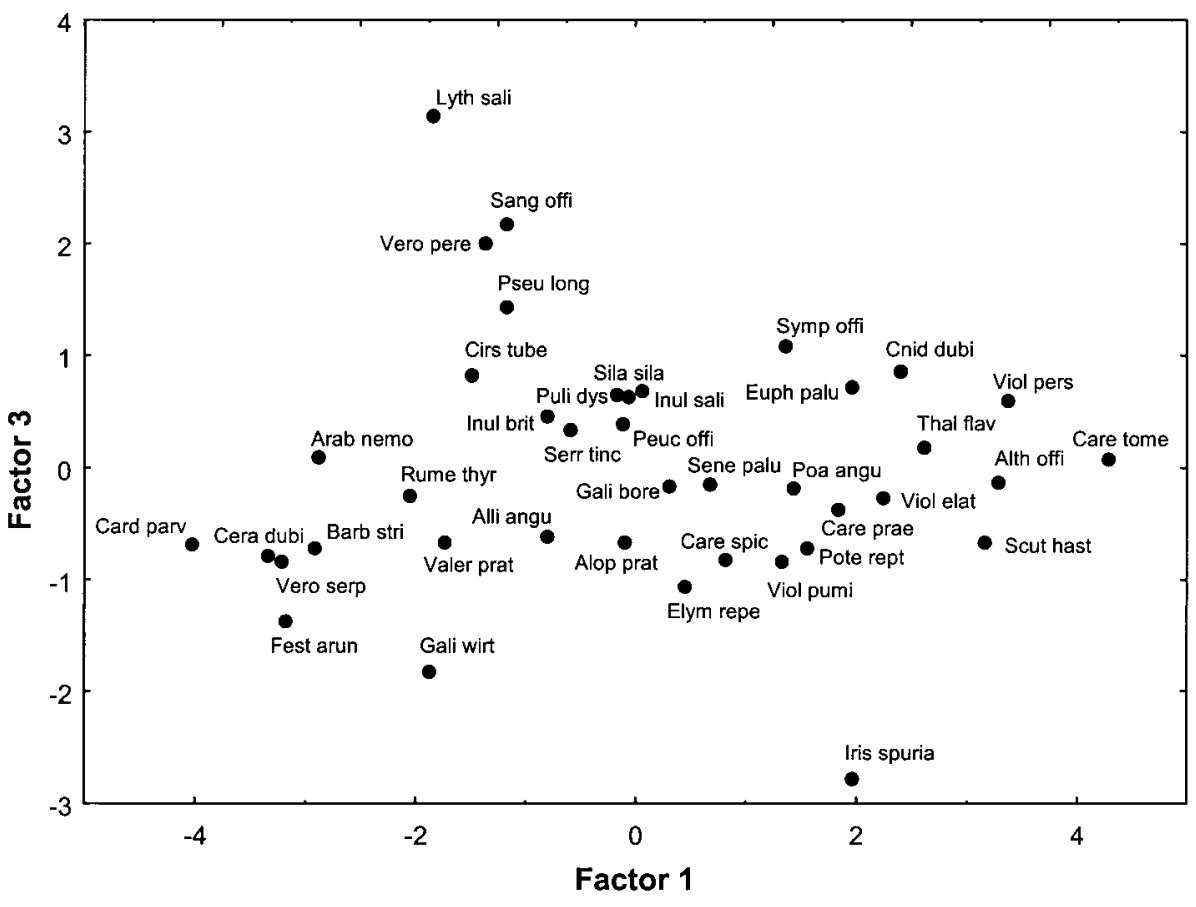

Fig. 2. Distribution of species in PCA ordination space along factor axes 1 and 3 (for abbreviations of species names see Table 1). confinement or Central European range size. Identical results (not shown) were obtained in group comparisons by the Mann-Whitney U-test.

\section{Discussion}

\subsection{Germination strategies in flood-meadows}

In flood-meadows of the studied type the survival of insufficiently developed seedlings will often be severely hampered by frost damage and prolonged flooding during the winter season (e. g. Voesenek \& Blom 1992). Equally, open patches with poor competition are more likely to occur in spring after the retreat of flood water, which often creates gaps in established vegetation. Consequently, it makes ecological sense that many of the flood-meadow species studied exhibited various levels of conditional or even strict dormancy in the year of shedding, while there were fewer species that germinated spontaneously at high rates over a wide temperature range including lower temperatures.

The existing diversity of germination response types in flood-meadow species was clearly visible in PCAordination, which reflected a continuous gradient of increasing dormancy levels along the first factor axis (Fig. 1) with Cardamine parvifolia (non dormant) and Carex tomentosa (highly dormant) as the most extreme points of the spectrum (Fig. 2). An almost identical main gradient in germination traits was found by $\mathrm{Ol} \mathrm{ff}$ et al. (1994) in the flora of Dutch wet meadows.

A high capacity for spontaneous germination directly after shedding is typical of many dominant Poaceae in temperate grasslands (Thompson \& Grime 1979), which could be confirmed in our study for Festuca arundinacea. The relatively low total germination rates compared to other studies (Grime et al. 1981) achieved in some dominant grasses of flood-meadows, such as Alopecurus pratensis, Elymus repens and Poa angustifolia, are probably partly due to heavy mildew infestation within the climate chamber treatments and/or low quality of the seeds used.

According to Grime (2001) two major strategies can be distinguished that enable seeds to delay germination until the following spring and summer season: i) high temperature requirements for germination, which are usually not fulfilled during the autumn season, ii) a requirement for chilling to break dormancy. In accordance with Wa sh it an i \& Ma su da (1990), who studied germination characteristics in a moist tall grassland community in Japan, both strategy types could be found. However, our study clearly established that some species may combine both principal strategies for the avoidance of harmful late autumn and winter germination. Within the year of shedding many of the studied species such as Allium angulosum, Arabis nemorenis, Cirsium tuberosum, Pseudolysimachion longifolium and others showed relatively high temperature requirements to reach significant germination rates, but came out of pri- 
I Cardamine paniflora

Cerastium dubium

II Euphorbia palustris

Valeriana pratensis

Cirsium tuberosum

Inula salicina

Arabis nemorensis

Allium angulosum

Pseudolysimachion long.

Serratula tinctoria

III Peucedanum officinale

Silaum silaus

Selinum carvifolia

Cnidium dubium

Galium boreale

Viola pumila

IV Inula britannica

Carex tomentosa

Althaea officinalis

Scutellaria hastifolia

Iris spuria

Lathyrus palustris
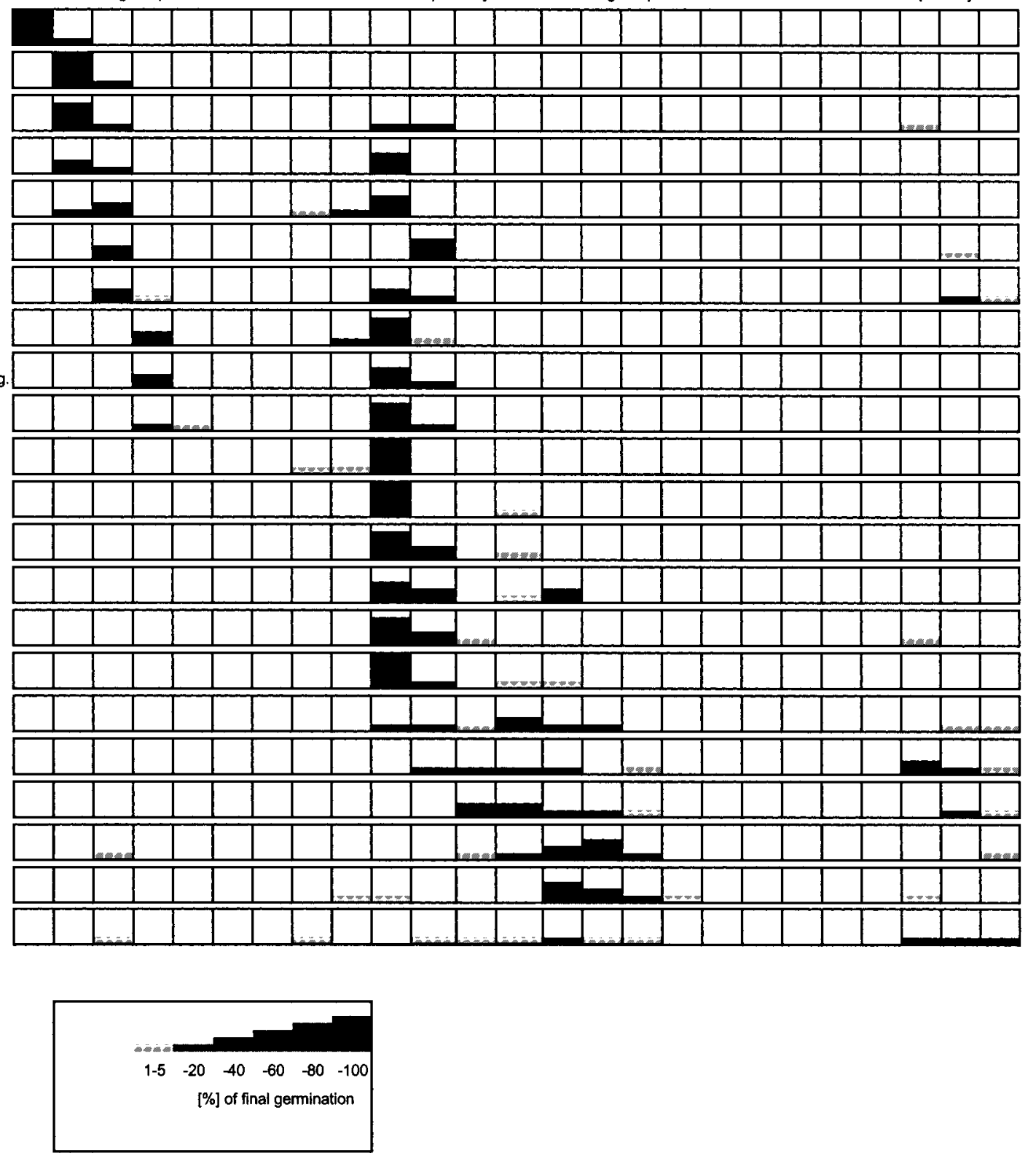

Fig. 3. Timing in germination of freshly shed seeds under outdoor conditions.

mary conditional dormancy (Baskin \& Baskin 2001) after a period of cold wet stratification. This phenomenon could be observed in the climate chamber treatments as well as under outdoor conditions. Ecologically this means that germination will stop well before the onset of the cool season while the same species are able to exploit gaps at relatively low temperatures in early spring.

Under natural habitat conditions in flood-meadows dormancy after shedding will often also be enforced by environmental constraints such as drought or shading through established vegetation. Additionally, in some species with high temperature requirements such as Arabis nemorensis, Inula britannica and Sanguisorba officinalis autumn germination is simply avoided by a strongly delayed seed release.

Besides conditional dormancy enforced by high temperature requirements prior to chilling, hardening of seed shells due to dry and warm weather conditions (or dry storage prior to laboratory experiments) may also be responsible for poor germination in the year of shedding (e. g. Ot t e 1996, Jen sen 2001). This applies in parti- 
cular to species that lack a response to the stratification treatment in the climate chamber but have high early spring germination rates such as Barbarea stricta, Viola elatior and $V$. pumila or those with strongly increased outdoor germination rates such as Allium angulosum, Euphorbia palustris and Galium boreale. All these species exhibit relatively hard and compact seed shells that obviously require softening in the course of prolonged outdoor stratification. In particular, Euphorbia palustris showed a high initial germination rate only in seeds sown directly after shedding. When seeds were dry stored and sown in winter germination extended over a much longer period. This phenomenon may be referred to as secondary induced physical dormancy (Ba skin \& Ba skin 2001).

As in other studies (Grime et al. 1981; Patzelt 1998) Apiaceae proved to exhibit a strict chilling requirement due to morphophysiological dormancy caused by an underdeveloped embryo (St okes 1952; Baskin \& Ba skin 2001), which necessarily delays germination until the spring season.

In accordance with Mil berg \& Andersson (1998) we found that differences in conditional dormancy were largely compensated by cold stratification under outdoor conditions resulting in a highly synchronised germination peak in March and early April. However, there was also a group of species in which high temperature requirements did not disappear after chilling. Althaea officinalis, Potentilla reptans, Thalictrum flavum and Scutellaria hastifolia and the Carex-species obviously require an obligatory extended period of warm moist incubation under outdoor conditions to come out of dormancy. This confers with results reported by other authors (Baskin \& Baskin 2001; Pat zel t 1998; Schüt z 1997, 2000a; Zir on 2002). In most of these species, high temperature requirements go hand in hand with a strongly delayed and asynchronous germination over the whole summer period. Conspicuously, species with the most delayed and asynchronous germination have relatively large and compact seeds with features of physical dormancy such as water-impermeable testa (Lathyrus palustris) or particularly thick and hard seed coats (Carex tomentosa, Iris spuria). After the breaking of physical dormancy, at least Lathyrus palustris and Iris spuria exhibited no particular temperature requirements for germination, as has been found in other studies for species of the same genera (Ba skin \& Baskin 2001; Grime et al. 1981).

Asynchronous germination can be seen as a strategy to minimise the risk of total failure of seed regeneration due to regularly occurring disruptive environmental constraints such as drought, which is particularly relevant in species with a delayed germination during summer. Equally, this strategy seems to be a benefit in amphibious habitats with strongly fluctuating moisture conditions. Consequently, in our study high temperature requirements and/or delayed and asynchronous germination were most common in perennial species with a clear preference for the dampest parts of flood-meadows such as Euphorbia palustris, Lathyrus palustris, Scutellaria hastifolia, Thalictrum flavum and Viola persicifolia. According to Grime et al. (1981) and Ba skin \& Baskin (2001) high temperature requirements and dormancy levels are a common feature in temperate wetland species.

\subsection{Germination characteristics and seed bank persistence}

In previous studies (Hölzel \& Otte 2001; 2003/4a) species, such as Arabis nemorensis, Cardamine parviflora, Cerastium dubium, Lythrum salicaria, Pseudolysimachium longifolium, Potentilla reptans, Veronica peregrina, $V$. serpyllifolia were revealed to build up large long-term persistent seed banks. Surprisingly, with the exception of Potentilla reptans, all these species exhibited relatively low dormancy levels and a high potential for fast germination in light. Thus, the formation of a long-term persistent soil seed bank is obviously completely due to dark dormancy. Typically, all these species have very small seeds, which according to Gr ime (2001) almost generally show an obligatory light requirement for germination. There seems to be an interesting link between the higher probability of burial in small seeds (Th ompson et al. 1993; Bekker et al. 1998) and their capacity for fast and almost complete germination in light. Species with regeneration strategies involving a large persistent soil seed bank typically exploit gaps in established vegetation caused by stochastic, largely unpredictable disturbances (Thompson \& Grime 1979; Grime 2001). Thus, the ability of spontaneous and rapid germination after exposure to light is an essential prerequisite for the successful exploitation of such temporary gaps. This strategy is of particular importance in ephemeral annuals of flood-meadows like Cardamine parviflora, Cerastium dubium and Veronica peregrina. However, even among these annuals significant differences could be found in the main period of germination. Cerastium dubium exhibited a delayed germination directly after shedding obviously due to a requirement for warm stratification to come out of dormancy at high temperatures, which is typical of facultative winter annuals (e. g. Ba skin \& Ba sk in 1983a). In seed bank experiments (Höl z el \& Ot t e 2001) this species showed a pronounced germination peak in late summer and early autumn. Equally, mass occurrence of Cerastium dubium in the field coincides with years of low winter flooding intensity (Höl z el 1999). In contrast, Veronica peregrina is preferably a summer annual 
due to its strong response to cold wet stratification, which was also found by Baskin \& Baskin (1983b).

Some species exhibiting particularly high dormancy levels such as Carex tomentosa and Viola persicifolia were also found to create long-term persistent soil seed banks (Höl zel \& Ot t e 2003/4a). However, their densities were usually much lower than in small seeded species, which may be caused by a lower probability of burial as well as a higher potential for germination in darkness (Grime 2001). Our results suggest that only in relatively large seeded species dormancy levels established in germination experiments are a good predictor for the capacity of a certain species to build up persistent seed banks.

\subsection{Germination characteristics and rarification}

We did not find any single germination trait or a multivariate response type that corresponded with the confinement of species to large river corridors. There appears to be nothing really particular in the germination behaviour of river corridor plants that could explain their conspicuous habitat and range restriction in Central Europe. A comparable set with similar variability in germination traits has been found in other temperate wet grassland communities (Wa sh it a ni \& Masuda 1990; Olff et al. 1994; Patzelt 1998; Jensen 2001).

Equally, there were no significant differences in germination characteristics between species with small or large Central European range. Comparable results were obtained by Th o mpson et al. (1999) who found no relationship between germination traits and range size of vascular plants in the British flora. Although there was a significant albeit weak trend for higher dormancy levels in endangered species, we found little evidence for the assumption made by Sch üt z (2000 b) that germination traits may play a prominent role in the causal understanding of rarity and decline. Regeneration characteristics are obviously outweighed by other species traits such as habitat specialism and the respective life strategy in the established phase, which have proved to be much better predictors of rarification processes in the Western and Central European flora (Korneck et al. 1998; Thompson et al. 1999; Grime 2001).

\subsection{Conclusions for restoration management}

In species with high temperature requirements causing delayed and asynchronous summer germination, recruitment in flood-meadows will often fail due to drought and competition through established vegetation. The frequent failure of regeneration by seeds does not usually diminish the viability of existing populations, since most of the relevant species are long-lived and exhibit extensive clonal growth. In contrast, this could become a serious problem in habitat restoration, in which species re-establishment crucially depends on regeneration by introduced seeds (e. g. Pat zel t 1998). In a plant material transfer experiment aimed at recreation of a species-rich flood-meadow (Höl z el \& Ot t e 2003), we found poor establishment success after four years in a number of species with delayed and asynchronous germination behaviour, such as Lathyrus palustris, Scutellaria hastifolia, Thalictrum flavum and almost all Carex species. Especially in Carex species the very specific and narrow germination requirements are obviously a major constraint and may explain their notoriously low colonisation capacity (Grime et al. 1988; Budel sky \& Galat owit sch 1999; Schütz 2000a). In most species with high germination temperature requirements, successful regeneration by seeds is probably confined to certain years with particularly favourable moisture conditions and low competition by established vegetation, as may occur in the course of prolonged early summer flooding and following drawdown (Jut il a 2001; Höl zel \& Ot te 2003, 2003/4b).

As demonstrated in this study the majority of floodmeadow species are able to exploit the particular favourable recruitment conditions (constant moisture supply, open vegetation structure) prevailing in early spring (March/early April). Management schemes that support the creation of open vegetation structures and patches of bare soil at this time of the year - such as mowing and removal of plant litter, aftermath pasture or scarring of the sward - may actively enhance regeneration by seeds (e.g. Kot or ová \& Lepš 1999).

\section{Acknowledgements}

We are grateful to Mart in a Dehn, Christ iane Lenz-Kuhl and Josef Schol z-vom Hofe for their help with in collecting seeds and performing germination experiments. Tobias Donath and Lut z Eckst ein provided helpful comments to a former version of this manuscript and Rod Snowdon polished our English. The comments of two anonymous referees greatly improved the quality of this paper. Our work was partly supported by grants from the Federal German Agency for Nature Conservation (BfN).

\section{References}

Bakker, J. P. \& Ber en dse, F. (1999): Constraints in the restoration of ecological diversity in grassland and heathland. - Trends Ecol. Evol. 14: 63-68.

Baskin, J. M. \& Baskin, C. C. (1983 a): Germination ecology of Veronica arvensis. - J. Ecol. 71 : 57-68. 
Baskin, J. M. \& Baskin, C. C. (1983b): Seasonal changes in germination responses of seeds of Veronica peregrina during burial, and ecological implications. - Can. J. Bot. 61: $3332-3336$

Ba skin, J. M. \& Ba skin, C. C. (2001): Seeds. - Acad. Pr., San Diego.

Bekker, R. M.; Bakker, J. P.; Gr andin, U.; Kal a mees, R.; Mil ber g, P.; Poschlod, P.; Thompson, K. \& Will ems, J. H. (1998): Seed size, shape and vertical distribution in the soil: indicators of seed longevity. - Funct. Ecol. 12: $834-842$.

Budel ski, R. A. \& Gal at ow it sch, S. M. (1999): Effects of moisture, temperature, and time on seed germination of five wetland Carices: Implications for restoration. Restor. Ecol. 7: 85-97.

Bundesamt für Nat urschutz (BfN) (2003): Flora-Web. http://www.bfn.de/08/index.htm (viewed 30.04.2002)

Burkart, M. (1998): Die Grünlandvegetation der unteren Havelaue in synökologischer und syntaxonomischer Sicht. - Arch. naturwiss. Dissertat. (Martina Galunder Verlag, Wiehl) Bd. 7: 1-157.

Burkart , M . (2001): River corridor plants (Stromtalpflanzen) in Central European lowland: a review of a poorly understood plant distribution pattern. - Global Ecol. Biogeogr 10: 449-468.

Dist er, E. (1980): Geobotanische Untersuchungen in der hessischen Rheinaue als Grundlage für die Naturschutzarbeit. - Doctoral Thesis, University Göttingen.

Ell en berg, H.; Düll, R.; Wirth, V.; Werner, W. \& Pau 1 issen, D. (1992): Zeigerwerte von Pflanzen in Mitteleuropa, 2. Aufl. - Scrip. Geobot. 18: 1-258.

Gr ime, J. P. (2001): Plant strategies, vegetation processes, and ecosystem properties. $-2^{\text {nd }}$ edition, John Wiley \& Sons, Chichster.

Grime, J. P.; Mason, G.; Curt is, A. V.; Rodman, J.; Band, S. R.; Mowforth, M. A. G.; Neal, A. M. \& Shaw, S. (1981): A comparative study of germination characteristics in a local flora. - J. Ecol. 69: 1017-1059.

Gr ime, J. P.; Hod g son, J. G. \& Hu n t, R. (1988): Comparative plant ecology. A functional approach to common British species. - Unwin Hyman, London.

Grubb, P. J. (1977): The maintenance of species-richness in plant communities: the importance of the regeneration niche. - Biol. Rev. 52: 107-145.

Höl zel, N. (1999): Flora und Vegetation der Auenwiesen im NSG „Lampertheimer Altrhein“ - eine aktuelle Zustandsanalyse mit Hinweisen zur zukünftigen Pflege und Entwicklung. - Jahrb. Naturschutz in Hessen 4: $24-42$.

Hölzel, N. \& Harnisch, M. (2002): Renaturierung von Stromtalwiesen. - Garten und Landschaft 112/8: 36-38.

Hölzel, N. \& Ot te, A. (2001): The impact of flooding regime on the soil seed bank of flood-meadows. - J. Veg. Sci. 12: 209-218

Höl zel, N. \& Ot te, A. (2003): Restoration of a species-rich flood meadow by topsoil removal and diaspore transfer with plant material. - Appl. Veg. Sci. 6: (in press).

Höl zel, N. \& Ot t e, A. (2003/4a): Assessing soil seed bank persistence in flood-meadows: which are the easiest and most reliable traits? - J. Veg. Sci. (accepted).

Höl zel, N. \& Ot t e, A. (2003/4b): Inter-annual variation in the soil seed bank of flood-meadows over two years with different flooding patterns. - Plant Ecol. (accepted).

Höl zel , N.; Don at h, T. W.; Bissel s, S. \& Ot t e, A. (2002): Auengrünlandrenaturierung am hessischen Oberrhein Defizite und Erfolge nach 15 Jahren Laufzeit. - Schr-R. Vegetationsk. 36: 131-137.

Hroudová, Z. \& Zákravsky, P. (2003): Germination responses of diploid Butomus umbellatus to light, temperature and flooding. - Flora 198: 37-44.

Hu l tén, E. \& Fr ies, M. (1986): Atlas of North European vascular plants: North of the tropic of cancer. - Koeltz Königstein.

Jen sen, K. (2001): Dormancy patterns and seed bank type of 20 temperate fen-grassland species. - EcoSys 34: 87-105.

Jutil a, H. M. (2001): Effect of flooding and draw-down disturbance on germination from a seashore meadow seed bank. - J. Veg. Sci. 12: 729-738.

Keller, M. \& Koll mann, J. (1999): Effects of seed proveance on germination of herbs for agricultural compensation sites. - Agr. Ecosyst. Environ. 72: 87-99

$\mathrm{Kn}$ ödl er , C. (2001): On the germination behaviour of widespread Festuca-Brometea and Molinietalia-species. Doctoral Thesis, University Giessen.

Korneck, D.; Schn it t ler; M. \& Voll mer, J. (1996): Rote Liste der Farn- und Blütenpflanzen (Pteridophyta et Spermatophyta) Deutschlands. - Schr-R. Vegetationsk. 28: 21-187.

Korneck,D.; Schnit t l er, M.; Kl ingen st ein,F.; Ludwig, G.; Takl a, M.; Boh n, U.\& May, R. (1998): Warum verarmt unsere Flora? Auswertung der Roten Liste der Farnund Blütenpflanzen Deutschlands. - Schr.-R. Vegetationsk. 29: 299-444.

Kor sch, H. (1999): Chorologisch-ökologische Auswertung der Daten der Floristischen Kartierung Deutschlands. Schr.-R. Vegetationsk. 30: 3-200.

Kot or ová, I. \& Lepš, J. (1999): Comparative ecology of seedling recruitment in an oligotrophic wet meadow. - J. Veg. Sci. 10: $175-186$.

Legendre, P. \& Legendre, L. (1998): Numerical Ecology. $2^{\text {nd }}$ ed., Elsevier, Amsterdam.

Leyer , I. (2002): Auengrünland der Mittelelbe-Niederung. Diss. Bot. 363: 1-193.

Mil ber g, P. (1994): Annual dark dormancy cycles in buried seeds of Lychnis flos-cuculi. - Ann. Bot. Fenn. 31: $163-167$.

Mil ber g, P. \& Andersson, L. (1998): Does cold wet stratification level out differences in seed germinability between populations? - Plant Ecol. 134: 225-234.

Olff, H.; Pegtel, D. M.; van Groenendael, J. M. \& Bakker, J. P. (1994): Germination strategies during grassland succession. - J. Ecol. 82: 69-77.

Ot t e, A. (1996): Population biological parameters to classify annual weeds. - J. Plant Disease Protec. Special issue 15: $45-60$.

Patzelt, A. (1998): Vegetationsökologische und populationsbiologische Grundlagen für die Etablierung von Magerwiesen in Niedermooren. - Diss. Bot. 297: 1-154.

Patzelt, A.; Wil d, U. \& Pfadenhauer, J. (2001): Restoration of wet fen meadows by topsoil removal: vegetation development and germination biology of fen species. Restor. Ecol. 9: 127-136. 
Rusch, G. \& Fern andez-Pal a cios, J. M. (1995): The influence of spatial heterogeneity on regeneration by seed in a limestone grassland. - J. Veg. Sci. 6: 417-426.

Ryser, P. (1993): Influences of neighbouring plants on seedling establishment in limestone grassland. - J. Veg. Sci. 4 : 195-200.

Schnit t l er, M. \& Günt her, K.-F. (1999): Central European vascular plants requiring priority conservation measures - an analysis from national Red Lists and distribution maps. - Biodiv. Conserv. 8: 891-925.

Sch ü t z, W. (1997): Primary dormancy and annual dormancy cycles in seeds of six temperate wetland sedges. - Aquat. Bot. 59: 75-85.

Sch üt z, W . (2000a): Ecology of seed dormancy and germination in sedges (Carex). Perspec. - Plant Ecol. Evol. System. 3: 67-89.

Schüt z, W . (2000b): The importance of seed regeneration strategies for the persistence of species in the changing landscape of Central Europe. - Z. Ökologie u. Naturschutz 9: $73-83$.

Silvert own, J. W . \& Dickie, J. B. (1980): Seedling survivorship in natural populations of nine chalk grassland plants. - New Phytol. 88: 555-558.

St a mpfl i, A. \& Zeit er , M. (1999): Plant species decline due to abandonment of meadows cannot be easily reversed by mowing. A case study from the Southern Alps. - J. Veg. Sci. 10: $151-164$

St okes, P. (1952): A physiological study of embryo development in Heracleum sphondylium L. I. The effect of temperature on embryo development. - Ann. Bot. 16: 441-447.
Th o mpson, K. \& Gr ime J.P. (1979): Seasonal variation in the seed banks of herbaceous species in ten contrasting habitats. - J. Ecol. 67 : 893-921.

Th o mpson, K.; Grime J. P. \& Ma son, G. (1977): Seed germination in response to fluctuating temperatures. Nature 67: 147-149.

Th o mpson, K.; Band, S. R. \& Hodg son, J. G. (1993): Seed size and shape predict persistence in soil. - Funct. Ecol. 7: $236-241$.

Th ompson, K.; Ga st on, K. J. \& Band, S. R. (1999): Range size, dispersal and niche breadth in the herbaceous flora of central England. - J. Ecol. 87 : 150-155.

Tou zard, B.; Amiau d, B.; Langl ois, E.; Lemau viel , S. \& Cl émen t , B . (2002): The relationships between soil seed bank, aboveground vegetation and disturbances in an eutrophic alluvial wetland of Western France. - Flora 197 : $175-185$.

Voesenek, L. A. C. J. \& Bl om, C. W. P. M. (1992): Germination and emergence of Rumex in river flood-plains. I Timing of germination and seedbank characteristics. Acta Bot. Neerl. 41: 319-329.

Wa sh it ani, I. \& Masuda, M. (1990): A comparative study of germination characteristics of seeds from a moist tall grassland community. - Funct. Ecol. 4: 543-557.

Wisskirchen, R. \& Haeu pl er, H. (1998): Standardliste der Farn- und Blütenpflanzen Deutschlands. - Ulmer, Stuttgart.

Zir on , C. (2000): On the germination behaviour of selected Plantaginetea majoris- and Molinio-Arrhenathereteaspecies. - Doctoral Thesis, University Giessen. 